\title{
Leaf litter is essential for seed survival of the endemic endangered tree Pouteria splendens (Sapotaceae) from central Chile
}

\author{
Gastón Javier Sotes $^{1,2}$, Ramiro Osciel Bustamante ${ }^{2,3}$, and Carolina Andrea Henríquez ${ }^{4}$ \\ ${ }^{1}$ Department of Botany, Faculty of Natural and Oceanic Sciences, University of Concepción, Concepción, Chile \\ ${ }^{2}$ Institute of Ecology and Biodiversity (IEB), Faculty of Sciences, University of Chile, Santiago, Chile \\ ${ }^{3}$ Department of Ecological Sciences, Faculty of Sciences, University of Chile, Santiago, Chile \\ ${ }^{4}$ Department of Biological Sciences, Faculty of Biological Sciences, \\ Andres Bello University, Santiago, Chile \\ Correspondence: Gastón Javier Sotes (gastonsotes@gmail.com)
}

Received: 31 August 2017 - Revised: 17 November 2017 - Accepted: 20 November 2017 - Published: 15 January 2018

\begin{abstract}
Pouteria splendens (A.DC.) Kuntze, the Chilean lúcumo, is an endemic tree and the only member of the Sapotaceae family in Chile. It is considered an endangered species as a consequence of its restricted distribution and small population size. Currently, individuals of $P$. splendens are immersed in a heterogeneous landscape with rocky mounds and plains located in areas densely populated by humans. Natural regeneration in the species seems to be low, despite the fact that plants are able to produce fruits. The species produces brightly colored fleshy drupes. There is no information about the dispersal pattern and the fate of the seeds. In this work we investigate (i) the seed dispersal pattern and (ii) the effect of tree canopy and the presence of leaf litter on seed survival, both in rocky mounds and plains. Results indicated an extremely low distance of seed dispersal, with most of the seeds falling down under the canopy. Seed survival under the canopy without leaf litter was very low and even zero in rocky mounds. Nevertheless, the presence of leaf litter covering the seeds increased survival in both habitats. Outside the canopy, seed survival only increased in plains. We suggest that future conservation programs should focus on protecting both adult plants and leaf litter under trees.
\end{abstract}

\section{Introduction}

Seed dispersal represents the starting point in the process of population recruitment (Harper, 1977). It also may influence population range expansion and spatial and genetic structures, both on local and landscape scales (Hamrick et al., 1993; Nathan and Muller-Landau, 2000; Wells and Young, 2002). The lack of seed dispersal can lead to reduction of seedling recruitment and finally lead to local plant extinction (Wang and Smith, 2002).

Seed dispersal by animals tends to increase plants regeneration through the deposition of the seeds in particular sites with high probability of survival (Wenny, 2001). This is because animal seed dispersers carry the seeds away from parent plants, decreasing the probability of seed mortality associated with host-specific parasites and predators (i.e., escape hypothesis) (Janzen, 1970). Also, in the case of fleshy fruits being dispersed, vertebrates can improve regeneration by removing the pulp from the seeds through their guts, increasing the capacity for seed germination (Traveset, 1998; Wenny, 2001; Reid and Armesto, 2011).

In the Chilean Matorral of central Chile, several woody endemic species present fleshy fruits with a diameter larger than $15 \mathrm{~mm}$ that apparently are not associated with an animal seed disperser at the present (Hoffman et al., 1989; Hoffmann and Armesto, 1995). One of these species is the Chilean lúcumo, Pouteria splendens (A.DC.) Kuntze (Sapotaceae), an evergreen tree with fleshy drupes of 25 to $35 \mathrm{~mm}$ diameter (Hoffman, 1980). Most fruits contain only one recalcitrant seed of 10 to $30 \mathrm{~mm}$ diameter (Nuñez-Prado, 2005). Actually, some local birds peck the pulp of $P$. splendens but the sizes of the fruits are larger than their gape width (Johow, 1948). There- 
fore, it is hypothesized that extinct Pleistocene megafauna were the legitimate dispersers of their seeds (Hoffman et al., 1989). As most of the shrubs and trees in the Chilean Matorral, $P$. splendens is distributed in isolated patches composed of adults plants immersed inside a matrix of herbs (Fuentes et al., 1984). P. splendens is located on rocky mounds and plains, a heterogeneous landscape formed by Pleistocene sea-level changes and tectonic events (Armesto et al., 2007). P. splendens's seedlings are more abundant under the canopies than outside the canopies when leaf litter is present (Sotes et al., 2013). Previous laboratory experiments showed that seed germination in the species tends to increase when the seeds are covered by leaf litter (Sotes et al., 2013). Also, the presence of leaf litter could be acting as a refuge against predators, since the type and density of leaf litter can change seed detectability by predators (Myster and Pickett, 1993). That could be important in trees growing up on rocky mounds since previous reports indicate that rocky sites act as a refuge for small mammals in central Chile (Simonetti and Otaíza, 1982).

The Chilean lúcumo was supposed to be more abundant in the past, but actually only a few isolated populations remain (Morales et al., 2015). It is considered a species seriously endangered (Squeo et al., 2001; Hechenleitner et al., 2005); however, the populations are not protected by the National Public System of Protected Areas (SNASPE) (Muñoz and Serra, 2006). Consequently, it is particularly important to investigate the factors that influence plant recruitment processes in this endangered species to design future plans of conservation and restoration. Therefore, in this study we present results from a survey aiming to assess the seed dispersal pattern, either under or outside the tree canopy, as well as the influence of leaf litter in seed predation in rocky mounds and plains.

\section{Materials and methods}

\subsection{Species and study area}

Pouteria splendens is the only member of the Sapotaceae family in Chile. It is considered an endangered species as a consequence of its restricted distribution and small population sizes. $P$. splendens trees reach heights of $5 \mathrm{~m}$ (Muñoz and Serra, 2006). Flowering and fruit production take place between September and April (Henríquez et al., 2012). Flowers are hermaphrodites, white and small $(5 \mathrm{~mm})$ (Hoffman, 1980; Muñoz and Serra, 2006). They are visited by insects like Diptera, Coleoptera and Hemiptera (personal observation). There is no published information about pollination in the species.

The study was carried out in the locality of Los Molles $\left(32^{\circ} 15^{\prime} \mathrm{S}, 71^{\circ} 30^{\prime} \mathrm{W}\right)$, the largest remaining $P$. splendens population, about $200 \mathrm{~km}$ north of Santiago, Chile. The climate of central Chile is Mediterranean, with rain concentrated in the winter months (Hajek and di Castri, 1976).
The vegetation in Los Molles is defined as coastal sclerophyllous forest (Squeo et al., 2001), dominated by Lithraea caustica (Molina) Hook. \& Arn. and P. splendens association (Lithreo-Lucumetum); among the most frequent and abundant species are Bahia ambrosioides Lag., Baccharis macraei Hook. \& Arn., Cryptocarya alba (Molina) Looser, Eupatorium salvia Colla, Fuchsia lycioides Andrews, Haplopappus foliosus DC., Peumus boldus Molina, Puya chilensis Molina and Sphacele salviae (Lindl.) Briq. (Mooney and Schlegel, 1967).

\subsection{Seed dispersal}

We randomly selected and marked 30 trees separated enough in space so as to avoid confounding the origin of the dispersed seeds. In each tree we marked four terminal branches, oriented according to the four cardinal points. The seed dispersal pattern was determined by following the fate of the seeds counted and marked with permanent paint in each of these four branches. Under and outside the canopy of each

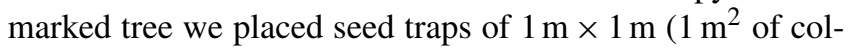
lecting area), with a base of nylon cloth (mesh size $1 \mathrm{~mm}$ ), at $0.5 \mathrm{~m}$ above the ground. We sampled the dispersed seeds outside the canopy up to a distance of $15 \mathrm{~m}$ from the limit of the canopy. Since the area outside the canopy was greater than below it, the sampling effort outside was increased. Therefore, for each marked tree we put 4 traps under the canopy and 8 traps outside (a total of 120 and 240 traps respectively). The experiment was carried out during March, which is the fruit production peak period (Henríquez et al., 2012).

\subsection{Seed survival}

We evaluated whether the habitat type (i.e., rocky mounds vs. plains) under or outside the tree canopy, as well as the presence of leaf litter, could influence seed survival after primary seed dispersal. For this, we collected $P$. splendens seeds, taking special care that they were not damaged by abiotic and/or biotic causes. We randomly selected 10 trees in both habitats. We placed 10 seeds on a dish open to seed predators under and outside the canopy of each selected tree. In addition, we placed 10 seeds covered with leaf litter under each focal tree canopy. Secondary seed dispersal has never been reported for P. splendens; therefore, we assumed that missing seeds were predated. Seed predation was considered either by the physical disappearance or by signs indicating partial consumption by animals. We quantified the remaining seeds and their state (with or without damage) every day for a period of 20 days.

\subsection{Data analysis}

The proportion of dispersed seeds under and outside the canopy was compared with a chi-squared test. Seed survival curves were obtained by applying the Kaplan-Meier method and they were compared using linear mixed-effects models 


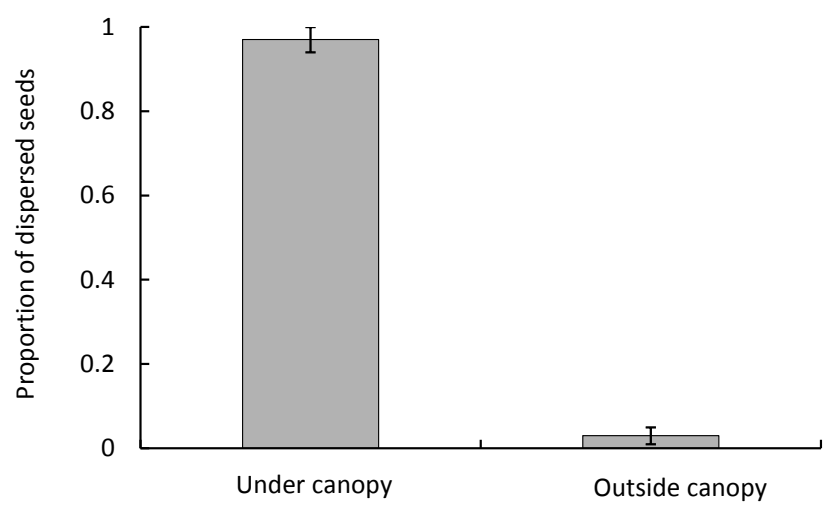

Figure 1. Dispersed seeds (mean $\pm \mathrm{SD}$ ) collected in traps, under and outside the canopy of $P$. splendens in Los Molles.

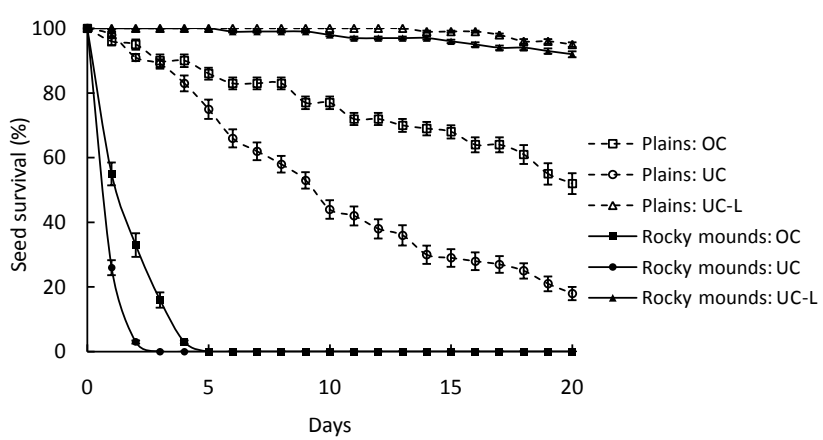

Figure 2. Seed survival curves (mean \pm SD) under the canopy of $P$. splendens, with and without leaf litter, and outside the canopy, both in plains and rocky mounds. UC, under canopy without leaf litter; UC-L, under canopy with leaf litter; OC, outside canopy.

and Tukey post-hoc multiple comparisons to discriminate differences among treatments. All tests were performed with a significance level of $5 \%$, using the program Statistica 6.0 (StatSoft Inc., Tulsa, OK, USA, 2001).

\section{Results}

\subsection{Seed dispersal}

Seed dispersal in $P$. splendens occurs by gravity; we found $96 \pm 4 \%$ (mean $\pm \mathrm{SD}$ ) of the fruits in traps under the canopy and only $4 \pm 3 \%$ outside (Fig. 1). The proportion of dispersed seeds was significantly greater under the canopy than outside it $\left(\chi^{2}=54.67, \mathrm{DF}=14, p<0.001\right)$.

\subsection{Seed survival}

In the plains, $18 \%$ of the seeds survived to day 20 under the canopy; however, this rate increased to $52 \%$ outside the canopy. The survival curves of these two groups are overlapping at first and on the third day they diverge (Fig. 2). In rocky mounds, the two curves diverge from the beginning; seeds under the canopy did not survive more than 3 days and not more than 5 days outside (Fig. 2). When seeds were covered by leaf litter the survival rate was higher than the uncovered seeds, being $95 \%$ under the canopy in plains and $92 \%$ in the rocky mounds (Fig. 2). On day 20, seed survival differed significantly among treatments $\left(F_{(5,53)}=32.48, p<\right.$ $0.001)$. However, no differences were found between under or outside the tree canopy in rocky mounds (Tukey test, $p=0.99$ ) and between leaf litter treatments (Tukey test, $p=0.99$ ).

\section{Discussion}

Despite the fact that Pouteria splendens produces fleshy drupes, there is no evidence that animals may act as seed dispersers, as most of the fruits fall under the canopy. Seed survival under the canopy was very low in plains and zero in rocky mounds. However, in the presence of leaf litter under the canopy, seed survival was very high in both habitats. Outside the canopy, seed survival only increased in plains.

The presence of big size fleshy fruits in $P$. splendens and the absence of actual animal dispersal indicated that it might be classified as an anachronism (Janzen and Martin, 1982). The paleo-history of the species might explain such anachronism. In fact, the Sapotaceae family and in particular the genus Pouteria have been described as one of the taxa that commonly have fruits dispersed by megafauna in the tropics (Gimarães et al., 2008). The Sapotaceae family has a Neotropical origin, and fruit traits in P. splendens might be related to this origin. Disturbance during the Cenozoic might explain the presence of larger fruits in the Mediterranean area of Chile. During the early Tertiary, tropical humid forest covered most of the area that now is known as the Mediterranean zone (Hinojosa and Villagrán, 1997). Climatic and geological events, such as the Pleistocene glaciations and the rising of the Andean chain, severely shrunk the area of forest distribution in southern South America, turning them into relicts (Armesto et al., 2007).

The absence of animal seed dispersers and the current climatic conditions might have important consequences on seedling emergence in P. splendens. Remnant populations are small and isolated, suggesting a strong limitation for gene flow, among and inside populations. Small population size and restricted gene flow might be associated with loss of genetic variation and inbreeding depression (Menges, 1991; Keller and Waller, 2002). Despite this, Morales et al. (2015) demonstrated that remaining $P$. splendens populations still maintain a high level of intra-population genetic diversity, and a notably low genetic differentiation between populations compared with other native tree species. Our results contribute to reject the hypothesis of high gene flow by seed dispersal; however, we cannot discard the idea of the maintenance of high levels of pollen-mediated gene flow. Unfortunately, there is no published information about pollination 
or pollen flow in the species. Morales et al. (2015), suggest that the genetic population pattern found might be the result of a recent process of habitat fragmentation and loss. Genetic variation among adult tree plants may reflect prefragmentation effect, whereas contemporary gene flow patterns will be observable among seedlings (Yineger et al., 2014). Consequently, it would be interesting to contrast the genetic pattern found in adult trees with the genetic variability in seedlings of $P$. splendens, since new generations might reflect patterns of more restricted gene flow through seeds.

Climatic conditions might also affect natural regeneration in $P$. splendens. Fruits are dispersed in summer, when humidity is reduced (Henríquez et al., 2012). Seeds are recalcitrant; consequently, there is a very short time period for germination following dispersal (Farnsworth, 2000). In a previous work, we found that germination increased significantly with periodic irrigation. Also, the presence of leaf litter under the canopy would increase seed germination probability by reducing the loss of seed and soil moisture (Sotes et al., 2013). In this study, we also found that leaf litter acts as a refuge against seed predators, especially in rocky mound habitats, which small mammals use to live (Simonetti and Otaíza, 1982).

In plains, seed survival under the canopy was very low too, probably because tree canopies offer a refuge to small mammals in central Chile (Simonetti, 1989). Seed survival outside the canopy tended to increase; however, the high temperature and low water availability during summer may reduce seed viability (del Pozo et al., 1989). Therefore, the environment immediately surrounding the seeds and its effects on the emerging seedlings are of critical importance in determining the dynamics of $P$. splendens populations. The protection provided by the leaf litter appears to be crucial for $P$. splendens regeneration. The same pattern has been described in ecosystems with strong environmental restrictions as arid or semiarid ecosystems (Callaway and Pugnaire, 1999; Becerra et al., 2004). Therefore, conservation programs for P. splendens should restrict the extraction of leaf litter for gardening, a common practice in central Chile (Lienlaf, 1996).

Data availability. Data are not available to the public as they are used for further analysis and research. Data are available on request.

Competing interests. The authors declare that they have no conflict of interest.

Acknowledgements. The study was supported by the Institute of Ecology and Biodiversity (IEB) FICM-P05-002.

Edited by: Daniel Montesinos

Reviewed by: Patricio García-Fayos and one anonymous referee

\section{References}

Armesto, J. J., Arroyo, M. T. K., and Hinojosa, L. F.: The Mediterranean environment of central Chile, in: The Physical Geography of South America, edited by: Veblen, T. T., Young, K. R., Orme, A. R., Oxford University Press, USA, 184-199, 2007.

Becerra, P. I., Celis-Diez, J. L., and Bustamante, R. O.: Effects of leaf litter and precipitation on germination and seedling survival of the endangered tree Beilschmiedia miersii, Appl. Veg. Sci., 7, 253-257, 2004.

Callaway, R. M. and Pugnaire, F. I.: Facilitation in plant communities, in: Handbook of Functional Plant Ecology, edited by: Pugnaire, F. I., Valladares, F., Taylor \& Francis Group, USA, 623648, 1999.

del Pozo, A. H., Fuentes, E. R., Hajek, E. R., and Molina, J. D.: Zonación microclimática por efecto de los manchones de arbustos en el matorral de Chile central, Rev. Chil. Hist. Nat., 62, 8594, 1989.

Farnsworth, E.: The ecology and physiology of viviparous and recalcitrant seeds, Annu. Rev. Ecol. Syst., 31, 107-38, 2000.

Fuentes, E. R., Otaiza, R. D., Alliende, M. C., Hoffmann, A. J., and Poiani, A.: Shrub clumps of the Chilean matorral vegetation: structure and possible maintenance mechanisms, Oecologia, 62, 405-411, 1984.

Gimarães Jr., P. R., Galetti, M., and Jordano, P.: Seed dispersal anachronisms: rethinking the fruits extinct megafauna ate, PLoS ONE, 3, e1745, https://doi.org/10.1371/journal.pone.0001745, 2008.

Hajek, E. R. and di Castri, F.: Bioclimatografía de Chile, Ediciones Universidad Católica de Chile, Santiago de Chile, 225 pp., 1976.

Hamrick, J. L., Murawski, D. A., and Nason, J. D.: The influence of seed dispersal mechanisms on the genetic structure of tropical tree populations, Plant Ecol., 107, 281-297, 1993.

Harper, J. L.: Population Biology of Plants, Academic Press, London, 892 pp., 1977.

Hechenleitner, P., Gardner, M. F., Thomas, P. I., Echeverría, C., Escobar, B., Brownless, P., and Martinez, C.: Ficha de Pouteria splendens (D.C.) Kuntze, in: Plantas Amenazadas del CentroSur de Chile, Distribución, Conservación y Propagación, Universidad Austral de Chile \& Real Jardín Botánico de Edimburgo, printed in Chile, 118-119, 2005.

Henríquez, C. A., Sotes, G. J., and Bustamante, R. O.: Fenología reproductiva de Pouteria splendens (Sapotaceae), Gayana Bot., 69, 251-255, 2012.

Hinojosa, L. F. and Villagran, C.: Historia de los bosques del sur de Sudamérica, I: antecedentes paleobotánicos, geológicos, y climáticos del Terciario del cono sur de América, Rev. Chil. Hist. Nat., 70, 225-239, 1997.

Hoffman, A.: Lúcumo silvestre (Pouteria splendens), in: Flora Silvestre de Chile, Zona Central, Fundación Claudio Gay, Chile, 52-53, 1980.

Hoffmann, A. J. and Armesto, J. J.: Modes of seed dispersal in the Mediterranean regions in Chile, California and Australia, in: Ecology and Biogeography of Mediterranean Ecosystems in Chile, California and Australia, edited by: Arroyo, M. T. K., Zedler, P. H., and Fox, M. D., Springer, USA, 289-310, 1995.

Hoffman, A. J., Teillier, S., and Fuentes, E. R.: Fruit and seed characteristics of woody species in mediterranean-type regions of Chile and California, Rev. Chil. Hist. Nat., 62, 43-60, 1989. 
Janzen, D. H.: Herbivores and the number of tree species in tropical forests, Am. Nat., 104, 501-528, 1970.

Janzen, D. H. and Martin, P. S.: Neotropical anachronisms: the fruits the Gomphoteres ate, Science, 215, 19-27, 1982.

Johow, E.: Flora de Zapallar, Rev. Chil. Hist. Nat., 49, 232-234, 1948.

Keller, L. F. and Waller, D. M.: Inbreeding effects in wild populations, Trends Ecol. Evol., 17, 230-241, 2002.

Lienlaf, E. F.: Estimación de la producción de hojarasca y su pérdida mediante la extracción de "tierra de hojas" en formaciones esclerófilas de la Reserva Nacional Río Clarillo, Tesis de Licenciatura, Facultad de Ciencias Agrarias y Forestales, Universidad de Chile, Santiago de Chile, 73 pp., 1996.

Menges, E. S.: The application of minimum viable population theory to plants, in: Genetics and conservation of rare plants, edited by: Falk, D. A. I. and Holsinger, K. E., Oxford University Press, USA, 45-61, 1991.

Mooney, H. A. and Schlegel, F.: La vegetación costera del cabo Los Molles en la provincia de Aconcagua, Boletín Universidad de Chile, 75, 27-32, 1967.

Morales, N. S., Fernández I. C., Carrasco, B., and Orchard, C.: Combining niche modelling, land-use change, and genetic information to assess the conservation status of Pouteria splendens populations in central Chile, Int. J. Ecol., 2015, 612194, https://doi.org/10.1155/2015/612194, 2015.

Muñoz, M. and Serra, M. T.: Estado de Conservación de las Plantas de Chile, Museo Nacional de Historia Natural y Comisión Nacional del Medio Ambiente (MNHN-CONAMA), Ficha de Antecedente de Especies $\mathrm{N}^{\circ}$ 133, Santiago de Chile, Comisión Nacional del Medio Ambiente, 2006.

Myster, R. and Pickett, S.: Effects of litter, distance, density and vegetation patch type on postdispersal tree seed predation in old fields, Oikos, 66, 381-388, 1993.

Nathan, R. and Muller-Landau, H. C.: Spatial patterns of seed dispersal, their determinants and consequences for recruitment, Trends Ecol. Evol., 15, 278-285, 2000.
Núñez Prado, P. B.: Manipulación de semillas y producción de plantas de lúcumo silvestre (Pouteria splendens (A.D.C.) O.K.), Tesis de Licenciatura, Facultad de Ciencias Forestales, Universidad de Chile, Santiago de Chile, 86 pp., 2005.

Reid, S. and Armesto, J. J.: Avian gut-passage effects on seed germination of shrubland species in Mediterranean central Chile, Plant Ecol., 212, 1-10, 2011.

Simonetti, J. A. and Otaíza, R. D.: Ecología de micromamíferos de Chile central: una revisión, Museo Nacional de Historia Natural de Chile, 38, 61-103, 1982.

Simonetti, J. A.: Microhabitat use by small mammals in central Chile, Oikos, 56, 309-318, 1989.

Sotes, G., Henríquez, C., and Bustamante, R. O.: Seedling distribution and seed germination of chilean lucumo (Pouteria splendens) in Los Molles, Rev. Chil. Hist. Nat., 86, 337-344, 2013.

Squeo, F. A., Arancio, G., and Gutiérrez, J. R.: Libro rojo de la flora nativa y de los sitios prioritarios para su conservación: Región de Coquimbo, Ediciones Universidad de La Serena, Santiago de Chile, Chile, 389 pp., 2001.

Traveset, A.: Effect of seed passage through vertebrate frugivores' guts on germination: a review, Perspect. Plant Ecol., 1/2, 151190, 1998.

Wang, B. C. and Smith, T. B.: Closing the seed dispersal loop, Trends Ecol. Evol., 17, 379-385, 2002.

Wenny, D. G.: Advantages of seed dispersal: a re-evaluation of directed dispersal, Evol. Ecol. Res., 3, 51-74, 2001.

Wells, G. P. and Young, A. G.: Effects of seed dispersal on spatial genetic structure in populations of Rutidosis leptorrhychoides with different levels of correlated paternity, Genet. Res., 79, 219226, 2002.

Yineger, H., Schmidt, D. J., and Hughes, J. M.: Genetic structuring of remnant forest patches in an endangered medicinal tree in north-western Ethiopia, BMC Genet., 15, 31, https://doi.org/10.1186/1471-2156-15-31, 2014. 